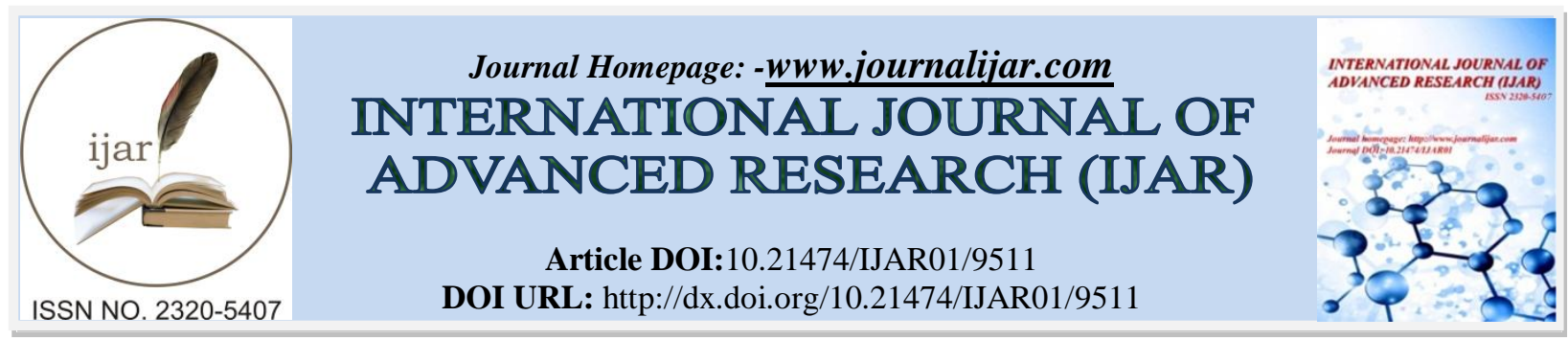

RESEARCH ARTICLE

\title{
EFFORTS TO BUILD SOCIAL CAPITAL IN IMPROVING MARKETING PRODUCT OF MICRO, SMALL AND MEDIUM ENTERPRISES (MSMEs).
}

\section{Elviati $^{1}$, Yonariza ${ }^{2}$, Endrizal Ridwan ${ }^{3}$ and Hasnah ${ }^{4}$.}

1. Post graduate student at Agriculture Science Study Program, Universitas Andalas, Indonesia / Agriculture Polytechnic of Payakumbuh, Lima Puluh Kota 26271 West Sumatera, Indonesia.

2. Agribusiness Department, Faculty of Agriculture,UniversitasAndalas, Indonesia.

3. Economics Department, Faculty of Economics, UniversitasAndalas, Indonesia.

4. Agribusiness Department, Faculty of Agriculture,UniversitasAndalas, Indonesia.

\section{Manuscript Info}

Manuscript History

Received: 06 June 2019

Final Accepted: 08 July 2019

Published: August 2019

Key words:-

MSMEs.marketing, social capital, build social capital.

\begin{abstract}
Social capital is a social relationship that can provide tangible benefits to the development of the organization, therefore it can be further understood as a resource. Social capital is seen as being able to increase the productive activities of business marketing. One proof of social capital is needed in marketing, especially in establishing business networks and cooperation for marketing, and therefore needs to be built to be well maintained. The purpose of this study is to analyze the use of social capital and efforts to build social capital in public companies in marketing products. This research uses a quantitative descriptive approach. Data obtained through in-depth interviews and direct observation. This study was conducted on 98 respondents of micro small and medium enterprises engaged specifically in local food processing. The results showed that MSMEs entrepreneurs in Payakumbuh, Indonesia had utilized social capital for product marketing activities such as trust, norms, networks, this was also encouraged by efforts to build social capital so that it continued to exist among business actors so that it could be utilized for marketing. The existence of social capital can encourage the solution of marketing problems through the improvement of business networks. Social capital that is built well by MSMEs can be a means to increase marketing.
\end{abstract}

Copy Right, IJAR, 2019,. All rights reserved.

\section{Introduction:-}

Business development is a part of the driving force of economic development. Another role that can be seen in addition to accelerating equitable economic growth in increasing the income of the business community is also able to provide employment. Limited business opportunities and employment opportunities spur people to use their own business as an opportunity so as not to depend on others. Business opportunities that are created will be able to run well if supported by the availability of markets and business products produced can market. Business groups that can provide employment are Micro, Small andMedium Enterprises (MSMEs). According to Herman (2012) the tendency of SMEs to have an increased contribution to economic growth and job creation.

Corresponding Author:-Elviati.

Address:-Post graduate student at Agriculture Science Study Program, UniversitasAndalas, Indonesia/ Agriculture Polytechnic of Payakumbuh, Lima Puluh Kota 26271 West Sumatera, Indonesia. 
Micro, Small and Medium Enterprises (MSMEs) is a form of small people's economy, where MSMEs are defined as economic actors who have a small capital, with limited human resources, and little understanding of the economy. Small and Medium Enterprises can now be considered as a savior valve for the country's economy because it can absorb labor when the country's economic conditions begin to recede (Abdullah and Hoetoro: 2011). The role of Micro and Medium Enterprises in increasing economic growth is very important, especially when the country's economic conditions are very difficult even though MSMEs can survive, this is because small scale businesses are not too dependent on large capital. Excess labor can also be utilized by MSMEs as providers of employment (Yassir; 2011).

For business development, MSMEs entrepreneurs need to pay attention to the economic dimension, especially sales. Sales that are only in one place and the lack of product development will affect business development (Ibrahim, Amanda, Gani, and Purnaningsih: 2013), so it can be said that market and product innovation is important to improve business development. According to Rehm and Goel (2017), the system of activities carried out by SMEs is a prerequisite for utilizing network connections in innovation and expanding company resources. Current world market demand must be able to be responded by MSMEs in providing product differentiation (Sudi and Atay: 2014) because it is an opportunity for MSMEs to be able to expand marketing.

Business development at MSMEs is closely related to the availability of raw materials, labor and business results that are automatically related to the market achieved and can compete in the market. Increased sales to promote the business as a step in achieving market expansion, in the process of Micro and Small and Medium Enterprises always involving people such as family, relatives, or other people employed, the role of social capital becomes important in forming networks and trust. However, the similarity of products produced by SMEs will create competition between businesses so they must be able to reach their markets.

According to Sarma, Dewi, and Siregar (2014) the development of small businesses is influenced by the motivation of entrepreneurs themselves in addition to policies by the government that facilitate entrepreneurs, so that increased sales will affect the development of businesses that are run, as well as the characteristics of entrepreneurs who are able to optimize productivity by increasing ability good competitiveness of the business itself.

The role of MSMEs is very important now because it is considered capable of being a savior of the Indonesian economy when the country's economy is declining. The results of the MSMEs Survey of the Organization of Economic Cooperation Development (OECD) can absorb labor by $70.3 \%$, but there are also many problems faced including weaknesses in product and market quality besides performance. MSMEs performance also determines the development of product marketing, according to Fatoki (2011) a positive relationship between various capital both human capital, social capital and financial capital and MSMEs performance looks very positive in influencing business, to be able to synergize for business progress. According to Send and Cowley (2013) MSMEs perform poorly in business ethics but social interactions with MSMEs stakeholders have a greater role, so it is necessary to build good interactions.

The commitment of the company in terms of employment has the potential for developing production and marketing. According to Sutopo (2011), wages and labor output have a positive effect on the amount of labor demand in Micro, Small and Medium Enterprises. Therefore, businesses must provide appropriate wages to produce good jobs.

The social performance at MSMEs is closer than that of professional contacts laden with the competition. This can be seen from the growing interaction of MSMEs among business actors, on the other hand, social capital is also built on development as a business unit that grows naturally without engineering. According to Sadiku-Dushi, Dana, and Ramadani (2019). SMEs in Kosovo have also utilized resources, opportunities and value creation in improving business performance, in addition to the adoption of innovation performance also becomes important according to Casidy, Nyadzayo, and Mohan (2019) in adopting innovative affective commitment becomes very important.

Utilization of social capital becomes an important variable for the growth and development of MSMEs as an impact of small-scale traditional business units so that interaction between MSMEs becomes more important (Ollila: 2006). To be able to increase business activities, social capital needs to be built, building social capital by expecting many informal contacts to be obtained to obtain marketing information (Felzensztein, Brodt \& Gimmon; 2014) because the information is very beneficial for marketing. 
Study on the use of social capital and efforts to build it needs to be done on MSMEs actors because MSMEs as a buffer of the community's economy needs business development by increasing sales through marketing. MSMEs is a small business group that needs to be encouraged to do business with a variety of competitors who want to get ahead that is associated with many actors (business actors, suppliers, distributors, and consumers) that are quite decisive in marketing so there needs to be social capital as a glue between business actors. The benefits of social capital which are very important with the inherent elements need to continue to be developed, but there has been no effort to explore so that the existing social capital can be built properly, as well as the benefits to business development. so the study of efforts to build social capital in the marketing of local food processing SMEs products is very important for marketing progress. Therefore the purpose of this paper is to analyze efforts to build social capital in SMEs and the use of social capital in product marketing.

\section{Research Method:-}

This research was conducted in Payakumbuh City, Indonesia, which was chosen deliberately because it is one of the regions that produce many food processing industries, especially cracker-type foods, regional-specific foods such as various kinds of rendang and other foods derived from local foods, Payakumbuh is a crossing area to other provinces and tourist destinations that are crowded to visit.

The sample in this study was determined from the sample criteria, namely the MSME category, engaged in the foodbased manufacturing industry that is the food industry that comes from local food. The number of samples that have been set according to the criteria is 98 respondents. Samples that have met the criteria are selected to become respondents then in-depth interviews are conducted.

This study is more focused on quantitative descriptive analysis that is describing and analyzing the use of social capital in marketing products and efforts made to build social capital within the reach of marketing, formed networks, and observing social phenomena experienced by objects research.

\section{Result:-}

Business actors in this research area are engaged in the field of local food processing. The products that are produced by MSMEs are various types of products and flavors. From the results of research in the field can be identified several types of products produced by MSMEs including, various crackers, various rendang, fried corn. These various products are a group of local food-based food processing industries. The many types of products with a variety of flavors made by MSMEs are an effort to diversify processed products. This diversification aims to develop markets and to provide different tastes that are tailored to the tastes of consumers.

\section{Characteristics of Respondents}

The characteristics of the respondents identified in the study area were related to the length of the business, the number of dependents and the gender of the entrepreneur who supported for the business activities carried out by the MSMEs

\section{Duration of Effort}

The business that is run by MSMEs in the research area is generally long-standing, business continuity is one of the objectives of the business actor in conducting business activities. Enterprises can continue if there is a market that accommodates products produced by business actors because the market is the final destination of a production process in business activities. From the results of the study, it can be seen that the length of a business carried out by business actors in the study area is quite long-lasting and sustainable, this can be seen in Table 1 below.

Table 1:-The length of time the business has been carried out by the responden

\begin{tabular}{|r|r|r|r|}
\hline Number & Long time effort & Frequency & $\%$ \\
\hline 1 & $1-5$ year & 13 & 13,2 \\
\hline 2 & $6-10$ year & 33 & 33,7 \\
\hline 3 & $11-15$ year & 27 & 27,6 \\
\hline 4 & $15-20$ year & 15 & 15,3 \\
\hline 5 & $21-25$ year & 4 & 6,1 \\
\hline 6. & $>25$ year & 98 & 4,1 \\
\hline & TOTAL & 980 \\
\hline
\end{tabular}


Table 1 it can be seen that the length of the business carried out by the business actor is at most in the 6-10 years running at $33.7 \%$. This illustrates that the business can run well. From table 1 it can also be seen that respondents have been in business for more than 20 years, at around $4.1 \%$ of the respondents, the results of the business interview are family-run businesses where the business has been run by the second generation as the successor of the business. The length of a business that was developed illustrates the power of creation and the will to develop the business. The long run of the business also illustrates the ability to overcome business problems and the existence of numerous business networks that continue to enable this business to continue to grow so that the business continuity is maintained.

\section{Amount of Dependents}

Dependents are an obligation for every head of the family to provide the best life for their children and families. The number of family members who are borne by parents will motivate someone to continue to be able to improve the performance of the business being run. From the results of the study the number of family dependents of the respondents varied, for more details can be seen in Table 2.

Table 2:-Number of dependents of respondent family members

\begin{tabular}{|r|r|r|}
\hline The number of dependents & Frequency & $\%$ \\
\hline $1-2$ people & 28 & 28,6 \\
\hline $3-4$ people & 36 & 36,7 \\
\hline $5-6$ people & 26 & 26,5 \\
\hline$>6$ people & 8 & 8,2 \\
\hline Total & 98 & 100 \\
\hline
\end{tabular}

Table 2 it can be seen that the number of dependents on family members ranged from 3 to 4 people, namely $37 \%$, and the lowest is in the range of $>6$ people, only about $8 \%$. This shows that respondents still have dependents, meaning that respondents still need funds to finance family life and educational interests of children, so that respondents must be able to try and will continue to strive to develop businesses that are run to continue to operate by getting a good market for the products they produce.

One of the goals of someone doing business is to get profits that will be used for living expenses and other costs, by doing a good business, the business actor hopes to get good profits too so that he gets a good life too

\section{Respondents' Gender Type}

MSMEs who are in the research area are more dominated by female workers because MSMEs processing is more an industry that is done at home so it is considered women have more than men in terms of business processing, for more details can be seen in Table 3:

Table 3:-Sex Respondent

\begin{tabular}{|r|r|r|r|}
\hline Number & Sex respondent & Frequency & $\%$ \\
\hline 1 & Male & 20 & 20,4 \\
\hline 2 & Female & 78 & 79,6 \\
\hline & Total & 98 & 100 \\
\hline
\end{tabular}

Table 3 it can be seen that MSMEs are more dominated by women workers because food processing has more ideas of creativity and diversity created by women. This ability to diversify food processing has the potential to gain market opportunities so that businesses can run and develop well. Perseverance, as well as the ability to gain markets, is also widely shared by female workers because female respondents are quicker to grasp market opportunities and to develop them.

\section{Utilization of Social Capital in Marketing}

Social capital in marketing MSMEs products becomes very important when businesses market products that have been produced. From the results of the study identified MSMEs have conducted various interactions so that with distributors, as well as suppliers of raw materials in marketing products. The good intertwined relationship between the actors becomes the capital to market the product, therefore businesses always try to maintain good relations continuously. Interactions that occur make MSMEs have a network and relationships with distributors, customers 
who are opportunities to base products. According to Fernandes, Belo and Castela (2016) managers feel the benefits of social networking in improving business performance. A well-developed network will increase sales to customers. According to Lin and Lin (2016), the network can create a well-embedded relationship between SMEs and partners to gain economic benefits by offsetting their weaknesses, because an increase in customers will have an impact on increasing production. Customers are the easiest actors in providing information, especially in innovation, according to Ioanid and Deselnicu (2018) increasing direct customers is something that can improve marketing. With the existence of networks and relations of MSME actors in the study area, the number of customers has increased directly as can be seen in Table 4 .

Table 4:-Recapitulation of value against the number of direct customers

\begin{tabular}{|l|l|l|l|l|}
\hline & \multicolumn{2}{|c|}{ Number of direct customers } & \\
\hline Value & No direct custumer & Little & Many & Total \\
\hline Total Respondent & 0 & 32 & 66 & 98 \\
\hline Percentage(\%) & 0 & 32,7 & 67,3 & 100 \\
\hline Average scor & \multicolumn{2}{|l|}{} & 2,67 \\
\hline
\end{tabular}

Table 4 it can be seen that MSMEs get direct customers by $67.3 \%$, this certainly has a good impact on the marketing of products made so that businesses will continue to maintain it. A large number of direct customers is also due to the access they have to the market where the business actors market their products.

This market access will affect business actors in conducting sales strategies. So that the products produced can compete with other products of a similar type, business people always try to improve quality and taste and price. For similar products, customers will compare with other similar products, so that MSMEs have a marketing strategy by knowing the prices of other products, so the prices given are also the same. Access to competitor prices also needs to be known so that businesses get consideration in marketing. From the results of the business actor's research, it is good enough to access the market potential as shown in table 5 .

Table 5:-Recapitulation of value of access to market potential

\begin{tabular}{|l|l|l|l|l|}
\hline & \multicolumn{3}{|c|}{ Access to market potential } & \\
\hline Value & No Access & Acces & Access well & Total \\
\hline Frequency & 15 & 58 & 25 & 98 \\
\hline Percentage(\%) & 15,3 & 59,2 & 25,5 & 100 \\
\hline Average score & \multicolumn{4}{|l}{} \\
\hline
\end{tabular}

Table 5 it can be seen that $25.5 \%$ of business actors have been able to access market potential well so that, it can be utilized for the sustainability of the business market being carried out, while 59.2\% have also been able to access the market, only $15.3 \%$ are can't access the market. The high ability of business actors to access the market is caused because businesses are in an area that is close to one another.

Product marketing is carried out by MSMEs by establishing good communication and interaction. Interaction between the SMEs and distributors in the study area has a good impact with the increase in the number of customers marketing the products made, the number of distributors obtained by the MSMEs in marketing the products can be seen in Table 6.

Table 6:-Recapitulation of the measurement value of the number of distributors in marketing theproduct

\begin{tabular}{|c|c|c|c|c|}
\hline Value & \multicolumn{3}{|c|}{ Number of distributors } & \\
\hline & 1 & $2-4$ & $>$ & Total \\
\hline Frequency & 16 & 24 & 58 & 98 \\
\hline Percentage $(\%)$ & 16,3 & 24,5 & 59,2 & 100 \\
\hline Avwrage score & & & & 2,4 \\
\hline
\end{tabular}

Table 6 it can be seen that MSMEs already have quite several customers, even more than $>4$ distributors owned by $59.2 \%$, proving that MSMEs have enough markets to accommodate products that are produced. 


\section{Efforts to Build Social Capital of MSMEs in Payakumbuh City}

The main foundation in building social capital can be demonstrated by the relationships that occur to other people who belong to the environment in which the community is located. The ability of a reliable and professional community by having an optimal capacity of social capital that enables it to take part, play a role and function as a partner, friend or colleague in the community, so that the community believes in its ability to be able to live and communicate with each other. According to Iturioz, Aragon, and Narvaiza (2015) in addition to social capital an intermediary is needed to extract social value to promote innovation in SMEs.

Society as a motor to drive development with the ability of capital owned to bring participation and participation in building a business is a manifestation of increasing social capital. Exploring the potential of existing resources in the form of improving the quality of natural and human resources as the main raw material in the business, improving the quality and ability to manage for entrepreneurs so that they can easily establish networks related to business and increase marketing. According to Gilmore, Carson, and Rocks (2006), Proakrif SMEs owners who establish relationships and take advantage of the network will get a better market.

The results of research in the field found that MSMEs practitioners continue to strive increase social capital with various efforts in running a business, especially to increase marketing. Some of the efforts made by MSMEs actors so that social capital is always well preserved are:

\section{Maintaining Social Relations and communication}

In general, every person needs a relationship with other human beings that are intertwined through communication as well as MSMEs in marketing the products that are produced, always having social relations and communication with both business people themselves and with distributors, customers, suppliers of raw materials and the government. This communication aims to improve good relations so that all can run smoothly. Communication in social relationships that occur is not only when they have to sell products but there are also social relationships in people's lives as social individuals such as interviews:

"... yes, a book to establish social relations, we also visit each other for friendship, giving each other news whether for other parties we try to visit each other. Our social relations continue to be well established because that's the way we are getting closer...."

$$
\text { (V.K, } 36 \text { Years) }
$$

This effort is carried out to increase social capital that has been well-established so that it has become a part of living for the community.

\section{Maintaining the culture and customary values that apply}

The culture and values prevailing in the community are guidelines in living life, for the MSMEs, the existing cultural values that become guidelines are always guarded so that mistakes and disputes do not occur so that they are safe in running their business such as not slandering other people's products.

\section{Maintain tolerance}

Business actors in the research area always do good with fellow business actors, people who are involved in marketing to respect and respect the minds of those around the business environment. The tolerance that is carried out by SMEs in the form of giving freedom to its members to be able to work and convey ideas for the development of products that are likely to be accepted in the market, such as a combination of taste, product size, and diversification of other products.

\section{Maintain honesty}

Honesty is the most important thing that is always applied by business actors. Always open, especially to employees who work and also to distributors and customers. To provide lessons for its employees, business actors apply termination sanctions for employees who are not honest, as well as distributors who are not honest in payments, MSMEs make a payment system at the beginning or even to termination of relations, but to prevent termination of the relationship, business actors try to find a distributor that can be trusted for timely payment, so that distributors who have been trusted will continue to be maintained and maintain the relationship, as quoted in the following interview. 
"...We always give priority to honesty, employees who are caught cheating we will stop as a deterrent effect so as not to do anymore where they work..."

\section{Increase confidence}

$$
\text { (V.m, } 36 \text { years old) }
$$

Efforts to increase trust with people involved in marketing through responsibility and commitment between business actors both to increase the amount of marketing and in maintaining business networks. This method is done by keeping promises, always on time, always meeting the needs of distributors and consumers as the following interview excerpts

"... To maintain confidence in the business we run, we always keep our promise and fulfill the demands of consumers and distributors well ..."

\section{Maintain social networks}

$$
\text { (Vn, } 36 \text { years old) }
$$

A well-established network continues to be maintained even enhanced so that business relationships are always maintained. This relationship is maintained by business actors with the people involved with it through a commitment that always maintains good business ties. Business ties that occur in SMEs have the advantage of lower costs, and also social ties have special benefits in aligning existing cultural norms Narooz and Child (2017). Finding new networks for marketing expansion is a must that is done so that customers and distributors continue to increase.

\section{Maintain togetherness and loyalty}

Togetherness is something that can increase social capital because each person feels that he is always being watched and given service. In this case, business actors to increase social capital continue to maintain togetherness and loyalty such as providing loans to employees who need funds, feel the distress also for distributors who experience disasters. Some activities are carried out jointly by business actors such as there is a time to go out with members at the end of the year to increase a sense of community.

\section{Commit the business}

Business actors always maintain joint commitments with suppliers, distributors, and customers. Sometimes suppliers need capital, then businesses will try to provide loans and pay on time, while distributors are always committed to providing good service and the amount and quality that is on- demand.

Increase a sense of togetherness and attention between people. Increasing the sense of togetherness is shown by increasing the community's empathy for the development of the community's environment and trying to always improve toward progress. Like visiting each other members, distributors, and customers who are experiencing a disaster, always giving news and communicating outside business activities. This activity aims to gain sympathy for people who are always in contact with SMEs. As the following interview excerpt

"... To maintain a sense of togetherness and attention between people, we always visit each other especially when there are an accident and death as well as provide good news that occurs between businesses involved in marketing activities ..."

\section{Discussion:-}

(F.D. 38 years)

The dimension of social capital lies in the ability of business actors to be able to build a business by strength social capital in trust, norms, and networks. In the reality of the day-to-day business, doers need to increase cooperation between fellow businesses to be able to access the market for the advancement of business marketing. But it needs a good commitment between business people with distributors and consumers in producing according to the taste and quality of food safety.

Price transparency as a commitment to service to consumers needs to be improved because consumers do not feel disadvantaged or feel they are buying products at very high prices and good quality and taste. The existence of social capital in MSMEs is very useful in marketing, especially to ensure the confidence of consumers and suppliers of raw materials, as well as fostering networks to expand marketing. According to Hernández-Carrión, CamareroIzquierdo and, Gutiérrez-Cillán (2019) to get access to social capital resources that are needed by entrepreneurs more in the diversity of networks and relational relationships. The marketing rules created by MSMEs themselves where the business actors will not take other people's customers who have been subscribed to by other business 
actors because MSMEs are more inclined individually and have become a habit in marketing the businesses that are run.

Marketing products that are oriented towards customer satisfaction by continuing to foster networks requires capital which we call social capital, in addition to human capital and financial capital. The emergence of this paradigm in marketing goods/products that were initially oriented towards financial capital, with the existence of social capital is considered able to increase customers by utilizing existing social capital such as trust, norms, and networks. According to Dowling, O'Gorman, Puncheva, and Vanwalleghem (2019) trust are a complex concept which is very important to understand the attitudes of SMEs. Trusting someone or caring for someone in fulfilling the interests of business actors in establishing cooperation for mutual benefit in the field of marketing. The trust that is built in the community as a business actor will provide a positive social life that can be utilized for business activities.

\section{Conclusion:-}

The identified social capital of business actors can all be beneficial for marketing activities, where business actors can develop social capital, access to markets, access to competitor prices, and interaction between business actors is quite good and have a positive commitment in supporting business marketing activities. The benefits of social capital include increasing cohesiveness, better responsibilities and increasing trust between business actors. To maintain the social capital of MSMEs, various businesses have been carried out by business actors including increasing several components of social capital such as social relations, communication, tolerance, commitment, and a sense of togetherness.

\section{Acknowledgement:-}

We express our gratitude to the Ministry of Research and Higher Education for providing assistance to study in this doctoral program, and also thank to University of Andalas as an education provider, as well as the AgriculturPolytechnic of Payakumbuh as a place for our institution to serve who has given permission to take this further education.

\section{References:-}

1. Abdullah, M.A., \&Hoetoro, A. (2011). Social entrepreneurship as an instrument to empowering small and medium enterprises an islamic perspective. Int. J. Manag. Bus. Res.1(1): 35-46.

2. Casidy,R., Nyadzayo, M., \&Mohan,M. (2019). Service innovation and adoption in industrial markets: An SME perspective. Industrial Marketing Management In Press. Available Online 24 june.

3. Dowling, M., O’Gorman,C., Puncheva, P., \&Vanwalleghem,V. (2019). Trust and SME attitudes towards equity financing across Europe. Journal of World Business, 54 : 101003.

4. Fatoki, O.O. (2011). The impact of Human, Sosial and Fnancial Capital on the Performance of Small Medium Entreprises in South Africa. J soc, sci. 29(3): 193-204.

5. Felzensztein, C., Brodt, S.E., \&Gimmon, E. (2014). Do strategic marketing and social capital really matter in regional clusters? Lessons from an emerging economy of Latin America. Journal of Business Research, 67(4): 498-507.

6. Fernandes networkenterprisebehaviorsandpatternsinSMEs:Lessons communitycenteredaroundthetourism industry. Technology and society, 44:15-22. Doi.org/10.1016/j.techsoc.2015.11.004

7. Gilmore, A., Carson, D., \& Rocks, S. (2006). Networking in SMEs: Evaluating its contribution to marketing activity. International Business Review, $15: 278-293$

8. Hernández-Carrión, C.,Camarero-Izquierdo, C., '\&Gutiérrez-Cillán, J . (.2019). The internal mechanism of entrepreneur’s social capital : A multi-network analysis.. BRQ Business Research Quarterly. In Pres.

9. Herman, E. (2012). SMEs and their Effect on theRomanian Employment. Procedia Economic and Finance. 3 , 290-297. Doi.10. 1016/s2212-5671(12)00154-2

10. Ibrahim, H.S., Amanah, D.S., Gani, dan Purnaningsih, N. (2013). Analisis keberlanjutan usaha Pengrajin Ekoonmi Kreatif Kerajinan Sutera di Provinsi Sulawesi Selatan. Jurnal Teknologi Industri Pertanian 23(3) : 2010-2019.

11. Ioanid, A., \&Deselnicu,D.C. (2018). The impact of social networks on SMEs' innovation potential. Procedia manufacturing, $22: 936-941$. 
12. Iturrioz, C., Aragon, C., \&Narvaiza, L. (2015). How to foster shared innovation within SMEs networks: Social capital and the role of intermediaries. Eur. Manage. J. 33:104 -115.

13. Lin, F., \& Lin, Y. (2016). The effect of network relationship on the performance of SMEs. Journal of Business Research . 69 (5) : 1780-1784.

14. Narooz, R., \& Child, J. (2017). Networking responses to different levels of institutional void: A comparison of internationalizing SMEs in Egypt and the UK.International Business Review, 26 (4) : 683-696.

15. Ollila, P. (2006). Principle of Institusional Economics with Aplication to Cooperative Entreprise. Working papers. No.56. Departemens of economics. Helsinki University.

16. Rehm, S., \&Goel, L. (2017). Using information systems to achieve complementarity in SME innovation networks. Information \& Management, $54: 438-451$.

17. Sadiku-Dushi, N., Dana, L., \&Ramadani,V. (2019). Entrepreneurial marketing dimensions and SMEs performance. Journal of Business Research 100:86-99.

18. Sarma, M., Dewi, F.R \&Siregar, E.H.. (2014). Small and household footwear industry Development toward Business sustainability and facing the China-ASEAN free Trade Agreement. Manajemen IKM, 9(1): 67-75.

19. Send, S., \& Cowley, J. (2013). The relevancy of stake holder theory and social capital theory in the contect of CSR In SMEs, An Australian perspective.J. Bus. Ethnic. 118: 413-427.

20. Sudi, A., \&Atay, E. (2014). GlobalInnovationandKnowledgeManagementPractice in Small and MediumEnterprises (SMEs) in TurkeyandtheBalkans. Procedia. Social and behavioral science. 150: 1260-1266. Doi: 10.1016/j.sbspro.2014.09.142.

21. Sutopo, I. (2011). ProduktivitasdanKetahananBisnisIndustri Kecil ( studiempirisindustri batik tulistrusmikecamatanpleredkabupatencirebon. Dinamikakeuangandanperbankan 3(1): 102-112.

22. Yasir, M., Majid, A., Ahmad, I., \&Tabassum, N. (2011). Structuring Intelectual Capital As An Element of virtual Organization in the SME Cluster. International Conference on Advanced management Science IPEDR 19 IA CSIT Press, Singapore. 175-181. 